\title{
Factors Influencing the Acid Lability of Substituted Arylsulphonyl Arginine Protecting Groups
}

\author{
Syed Safdar Ali ${ }^{\mathrm{a}}$, Hartmut Echner ${ }^{\mathrm{a}}$, Khalid Mohammed Khan ${ }^{\mathrm{a}}$, \\ Christoph Schröder ${ }^{\mathrm{a}}$, Mashooda Hasan ${ }^{\mathrm{a}}$, Atta-ur-Rahman ${ }^{\mathrm{b}}$, Wolfgang Voelter ${ }^{\mathrm{a}, *}$ \\ a Abteilung für Physikalische Biochemie des Physiologisch-chemischen Instituts \\ der Universität Tübingen, Hoppe-Seyler-Straße 4, D-72076 Tübingen, Germany \\ b HEJ Research Institute of Chemistry, University of Karachi, Karachi-75270, Pakistan \\ Dedicated to Prof. Dr. Tschesche on the occasion of his 60th birthday \\ Z. Naturforsch. 49b, 1425-1433 (1994); received May 16, 1994 \\ 2,4,6-Triisopropylbenzenesulphonyl (Tip), 4-Methoxy-3,5-di-tert-butylbenzenesulphonyl (Mtbs), \\ Phenanthrene-3-sulphonyl (Phen) Residues \\ The kinetics of hydrolysis of new, $\mathrm{N}^{\mathrm{G}}$-protected 2,4,6-triisopropylbenzene-sulphonyl (6), \\ 4-methoxy-3,5-di-tert-butylbenzenesulphonyl (12) and phenanthrene-3-sulphonyl (17) Fmoc \\ derivatives of $\mathrm{L}$-arginine (1) in comparison with commercially available $\mathrm{Fmoc}-\mathrm{Arg}(\mathrm{Mtr})-\mathrm{OH}$ \\ (Mtr = 4-methoxy-2,3,6-trimethyl-benzenesulphonyl (2)) are studies. The acid lability of the \\ arylsulphonyl group is decreasing as follows Mtr $>$ Tip $>$ Mtbs $>$ Phen. The effect of electron- \\ donating alkyl groups as substituents in increasing the acid lability of the arylsulphonyl resi- \\ due seems to be in the order of methyl > isopropyl > tert-butyl, while the effect of extended \\ delocalization does not appreciably increase the acid lability.
}

There exists still interest in the development of protecting groups for the guanidino function of arginine (1) cleavable under mild acidolytic conditions without causing side reactions. Most of the described and used protecting groups are subject to side reactions during their introduction or under the experimental conditions used in peptide synthesis [1]. The nitro group, introduced by Bergmann for peptide synthesis [2], allows $\delta$-lactam formation during activation, and nitroamidations of the free amino groups are observed [1]. Lactam formation can also not be prevented by using $\mathrm{N}^{\mathrm{G}}$-tosylated arginine derivatives [1] introduced by tosyl chloride [3]. Further efforts in this direction led to the use of urethane type groups, among them e.g. Fmoc- $\mathrm{Arg}(\mathrm{Boc})-\mathrm{OH}[4,5]$ or Fmoc- $\operatorname{Arg}(\operatorname{Adoc})_{2}-\mathrm{OH}[6,7]$ have been used as synthons for solid phase peptide synthesis. However, poor coupling and unstable side chain protection were observed during peptide formation $[8,9]$. In recent years, major efforts have been devoted to develop multi-substituted arylsulphonyl groups. The strategy for designing more acid labile protecting groups has been the addition

* Reprint requests to Prof. Dr. Dr. h. c. W. Voelter. of electron-donating groups to the phenyl ring of the arylsulphonyl moiety [10], leading to protecting groups with increasing acid lability: 4-methoxy-2,3,6-trimethylbenzenesulphonyl (Mtr) > 4-methoxy-2,6-dimethylbenzenesulphonyl (Mds) 2,4,6-trimethoxybenzenesulphonyl (Mtb) > 2,3,4,5,6-pentamethylbenzenesulphonyl (Pme) > 4-methoxy-2,3,5,6-tetramethylbenzenesulphonyl (Mte) > mesitylene-2-sulphonyl (Mts) p-methoxybenzenesulphonyl (Mbs) > 2-methoxy-4,6dimethylbenzenesulphonyl ( $i \mathrm{Mds})$. This concept lead to the development of the 4-methoxy-2,3,6trimethylbenzenesulphonyl (Mtr) group which is the most acid labile in this class and nowadays frequently used in peptide synthesis. Most of the $\alpha$-amino acid side chain protecting groups used in Fmoc-based solid phase peptide synthesis are easily cleaved with $95 \%$ TFA in $1.5 \mathrm{~h}$ at room temperature. In contrast, the removal of Mtr often requires a 5-6 h TFA/anisole/ethanedithiol [11] or TFA/thioanisole [12] treatment. Further search for an enhanced acid labile guanidino protecting group of arginine resulted in the development of 2,2,5,7,8-pentamethylchroman-6-sulphonyl (Pmc) [11] residue, which is rapidly cleaved by TFA or $50 \%$ TFA in dichloromethane at room temperature [11]. Fmoc-Arg(Pmc) was successfully used in the syntheses of various challenging multiple ar- 
ginine fragments of collagen $\alpha 1$ (I) (757-790) [13], ubiquitin (48-76) and $\beta$-melanocyte stimulating hormone [13]. On completion of the syntheses using Fmoc amino acids the side chain protection and cleavage from the resin was achieved in $1.5 \mathrm{~h}$ using $95 \%$ TFA $/ 3 \%$ anisole $/ 1 \%$ ethanedithiol $/ 1 \%$ ethyl methyl sulphide [13]. Unfortunately, the dilemma is still not solved. This is because of rather slow coupling, significant side reactions in the presence of tryptophan and less efficient acidolytic removal of both, the Mtr and Pmc group as compared to the other amino acid side chain protecting groups used in Fmoc-based syntheses [11, 14-16]. In view of these difficulties there is still an urgent need to have better $\mathrm{N}^{\mathrm{G}}$ protecting groups for arginine. A careful study of the results so far obtained with substituted arylsulphonyl protecting groups suggested $[10,11]$ that the acid lability of these groups depends upon the stability of the arylsulphonyl cation formed during the acidolysis. This in turn depends upon specific steric and electronic factors i.e. the nature and position of the electron-donating substituents present in the aromatic ring. Therefore, it seemed worthwhile to carry out a study of the effect of electron-donating alkyl substituents, e.g. isopropyl and tert-butyl, on the rate of acidic removal of substituted arylsulphonyl arginine protecting groups. For this purpose, two substituted arylsulphonyl residues, 2,4,6-triisopropylbenzenesulphonyl (Tip, 6) [17] and 4-methoxy-3,5-di-tert-butylbenzene sulphonyl (Mtbs, 12), are subjected to kinetic studies as guanidino protecting groups. Moreover, the effect of extended conjugation in arylsulphonyl residues on the acidic removal of the protecting groups is also studied. The third residue, phenanthrene-3-sulphonyl (Phen, 17), is prepared for studying this factor.

$\mathrm{N}^{\alpha}$-benzyloxycarbonyl-L-arginine

( $\mathrm{Z}-\mathrm{L}-\mathrm{Arg}-\mathrm{OH}, 3)$ is prepared according to a standard procedure by the reaction of L-arginine with benzyl chloroformate [18]. The Tip group is incorporated into $\mathbf{3}$ according to the procedure described in the experimental to obtain $\mathrm{N}^{\alpha}$ benzyloxycarbonyl- $\mathrm{N}^{\mathrm{G}}$-2,4,6-triisopropylbenzenesulphonyl-L-arginine ( $\mathrm{Z}-\mathrm{L}-\mathrm{Arg}(\mathrm{Tip})-\mathrm{OH}, 4)$. The $\mathrm{N}^{\alpha}$-benzyloxycarbonyl group is removed from 4 by catalytic hydrogenation over activated $10 \% \mathrm{Pd} / \mathrm{C}$ in glacial acetic acid. $\mathrm{N}^{\mathrm{G}}-2,4,6$-triisopropylbenzenesulphonyl-L-arginine acetate<smiles>N=C(N)NCCC[C@H](N)C(=O)O</smiles><smiles>N=C(N)NCCCCC(=O)O</smiles><smiles>[R]NC(=N)NCCC[C@]([2H])(NC(=O)Oc1ccccc1)C(=O)O</smiles>
$\mathrm{H}_{2} / \mathrm{Pd}(15 \% \mathrm{HBr} / \mathrm{ACOH})$

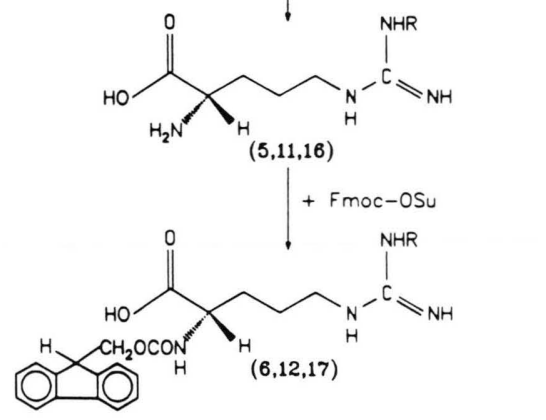

$R=2,4,6-$ Trisopropylbenzenesulphonyl (Tip), 4-Methoxy3,5-di-tert-butylbenzenesulphonyl (Mtbs), Phenanthrene-3 -sulphonyl (Phen)

( $\mathrm{H}-\mathrm{L}-\mathrm{Arg}(\mathrm{Tip})-\mathrm{OH}$. HOAc, 5) so obtained is converted to $\mathrm{N}^{\alpha}$-9-fluorenylmethyloxy-carbonyl$\mathrm{N}^{\mathrm{G}}$-2,4,6-triisopropylbenzenesulphonyl-L-arginine (Fmoc-L-Arg(Tip) $-\mathrm{OH}$, 6) by reacting it with Fmoc-OSu in acetonitrile.

The other arylsulphonyl residue (Mtbs) is synthesized by methylation of 2,6-di-tert-butylphenol to 2,6-di-tert-butylanisole (7) which in turn is sulphonated to 4-methoxy-3,5-di-tert-butylsulphonic acid potassium salt (8) with chlorosulphonic acid. Reaction of $\mathbf{8}$ with $\mathrm{PCl}_{5}$ and $\mathrm{POCl}_{3}$ yields the corresponding 4-methoxy-3,5-di-tert-butylbenzenesulphonyl chloride (9). $\mathrm{N}^{\alpha}$-Benzyloxycarbonyl$\mathrm{N}^{\mathrm{G}}$-4-methoxy-3,5-di-tert-butylbenzenesulphonyl$\mathrm{L}$-arginine $(\mathrm{Z}-\mathrm{L}-\mathrm{Arg}(\mathrm{Mtbs})-\mathrm{OH}, \mathbf{1 0})$ is then prepared by reacting the respective sulphonyl chloride with 3 in THF in the presence of $\mathrm{NaOH}$ 


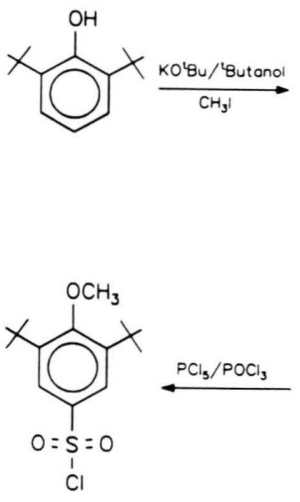

(9)

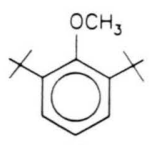

(7)<smiles>[X]OS(=O)(=O)c1cc(C(C)(C)C)c(OCC(C(=O)O)C(=O)O)c(C(C)(C)C)c1</smiles>

(8) as described in the experimental. Compound $\mathbf{1 0}$ is converted into the $\mathrm{N}^{\mathrm{G}}-4$-methoxy-3,5-di-tertbutylbenzenesulphonyl-L-arginine hydrobromide $(\mathrm{H}-\mathrm{L}-\mathrm{Arg}(\mathrm{Mtbs})-\mathrm{OH} \mathrm{HBr}, \mathbf{1 1})$ by reacting $\mathbf{1 0}$ with $15 \% \mathrm{HBr}$ /acetic acid. $\mathrm{N}^{\alpha}$-9-fluorenylmethyloxycarbonyl-N $\mathrm{N}^{\mathrm{G}}$-4-methoxy-3,5-di-tert-butyl-

benzenesulphonyl-L-arginine (Fmoc-L-Arg-

(Mtbs)-OH, 12) is obtained by the reaction of $\mathbf{1 1}$ with Fmoc-OSu under standard conditions as given in the experimental [19].

Phenanthrene-3-sulphonyl chloride (14) is prepared by sulphonation of phenanthrene with concentrated sulphuric acid [20]. The phenanthrene-3sulphonic acid potassium salt (13), obtained after work up, is converted into phenanthrene-3-sulphonyl chloride according to the procedure described for compound 9. $\mathrm{N}^{\alpha}$-Benzyloxycarbonyl$\mathrm{N}^{\mathrm{G}}$-phenanthrene-3-sulphonyl-L-arginine

(Z-L-Arg(Phen)-OH, 15) can be obtained by

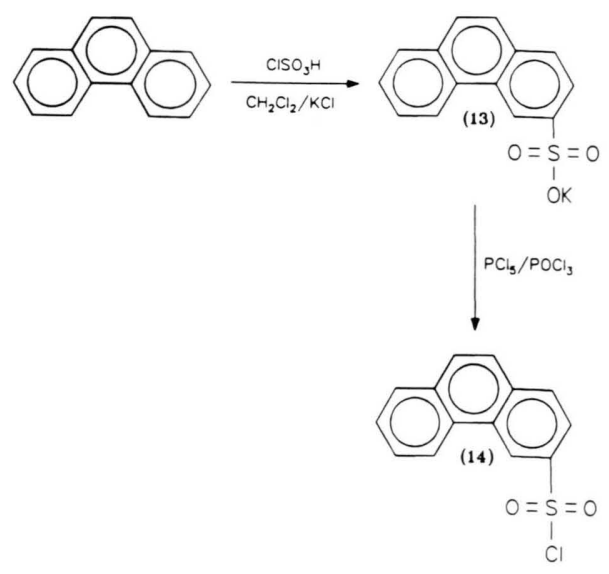

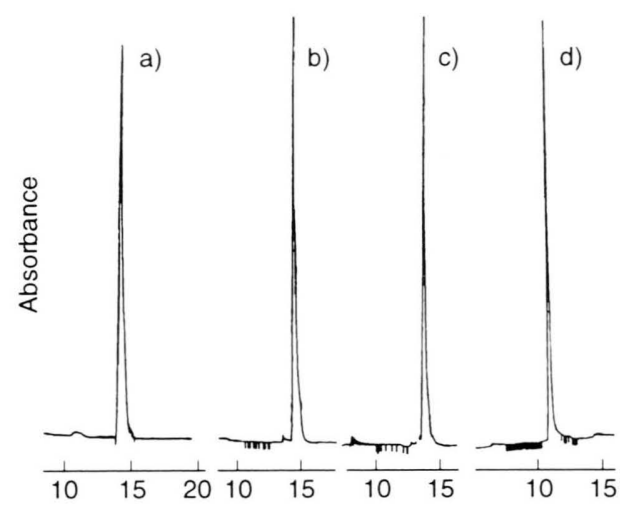

Fig. 1. Analytical HPLC of purified Fmoc-Arg derivatives. a) Fmoc-Arg(Mtr)-OH (2); b) Fmoc-Arg(Tip) $\mathrm{OH}$ (6); c) Fmoc-Arg(Mtbs)-OH (12); d) FmocArg(Phen)-OH (17). Chromatographic conditions: Column: Nucleosil 120-5 $\mathrm{C}_{18}$ (Macherey-Nagel, 250/1/4" $4.6 \mu \mathrm{m}$ ); eluents: $40 \% \mathrm{CH}_{3} \mathrm{CN}$ and $0.015 \%$ TFA in water (A), $80 \% \mathrm{CH}_{3} \mathrm{CN}$ and $0.015 \%$ TFA in water (B); linear gradient from 0 to $100 \%$ in $11 \mathrm{~min}$; flow rate: $1.2 \mathrm{ml} / \mathrm{min}$; concentration: $1 \mu \mathrm{g} / \mu \mathrm{l}$; injected volume: $25 \mu \mathrm{l}$; detection at $301 \mathrm{~nm}$.

the reaction of phenanthrene-3-sulphonyl chloride with 3. Removal of the $\mathrm{N}^{\alpha}$-benzyloxycarbonyl group from $\mathbf{1 5}$ is effected by its reaction with $15 \%$ $\mathrm{HBr}$ /acetic acid to obtain $\mathrm{N}^{\mathrm{G}}$-phenanthrene-3-sulphonyl-L-arginine bromide ( $\mathrm{H}-\mathrm{L}-\mathrm{Arg}(\mathrm{Phen})-$ $\mathrm{OH}$. $\mathrm{HBr}, \mathbf{1 6})$. Reaction of $\mathbf{1 6}$ with Fmoc-OSu results in the preparation of $\mathrm{N}^{\alpha}-9$-fluorenylmethyloxycarbonyl- $\mathrm{N}^{\mathrm{G}}$-phenanthrene-3-sulphonyl-Larginine (Fmoc- $\mathrm{L}-\mathrm{Arg}(\mathrm{Phen})-\mathrm{OH}, 17)$.

Melting points, $R_{f}$, optical activity, mass spectral data and elemental analysis of all synthesized compounds are given in the experimental which confirm the purity and structure of the synthesized compounds. The purity of $\mathbf{2 ,} \mathbf{6 , 1 2}$ and $\mathbf{1 7}$ is further verified with HPLC (Fig. 1) and compounds 2, 6, 12 and 17 are subjected to acid hydrolysis separately using TFA/methanesulphonic acid (MSA) (8:2). An HPLC solvent system is developed to study the kinetics of acidolytic removal of Tip, Mtbs and Phen (Fig. 3) in comparison with that of $\mathbf{2}$ (Fig. 2) using their Fmoc derivatives 6, 12, and $\mathbf{1 7}$ and commercially available Fmoc-L-Arg(Mtr)-OH. The results obtained are shown in Figs. 2 and 3, and Table I.

Compounds 6, 12, and 17 hydrolyzed at slower rate than 2. It is evident from Fig. 3 that substitution by the isopropyl and tert-butyl group in the aromatic ring of the arylsulphonyl residue is less 


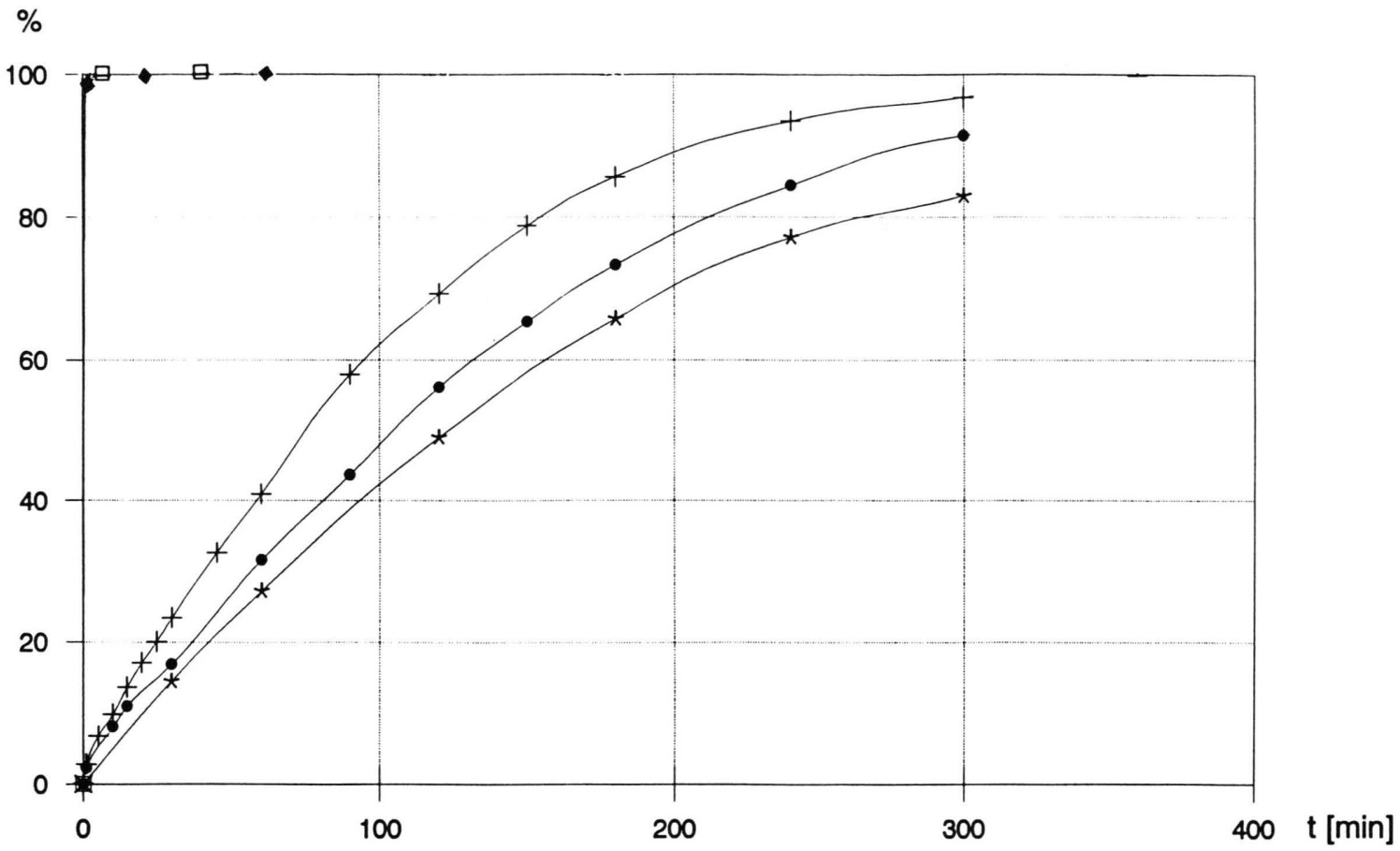

Fig. 2. Cleavage kinetics of the Mtr group from Fmoc-Arg(Mtr)-OH under the following acidolytic conditions: $*=$ TFA/anisole/water $(90: 5: 5) ; 0=$ TFA/water $(95: 5) ;+=$ TFA/ethanedithiol/water $(90: 5: 5) ;$ (90:10); $\square=$ TFA/MSA $(80: 20)$. For chromatographic conditions, see legend to Fig. 1 and for kinetic investigations, see experimental.

$\%$

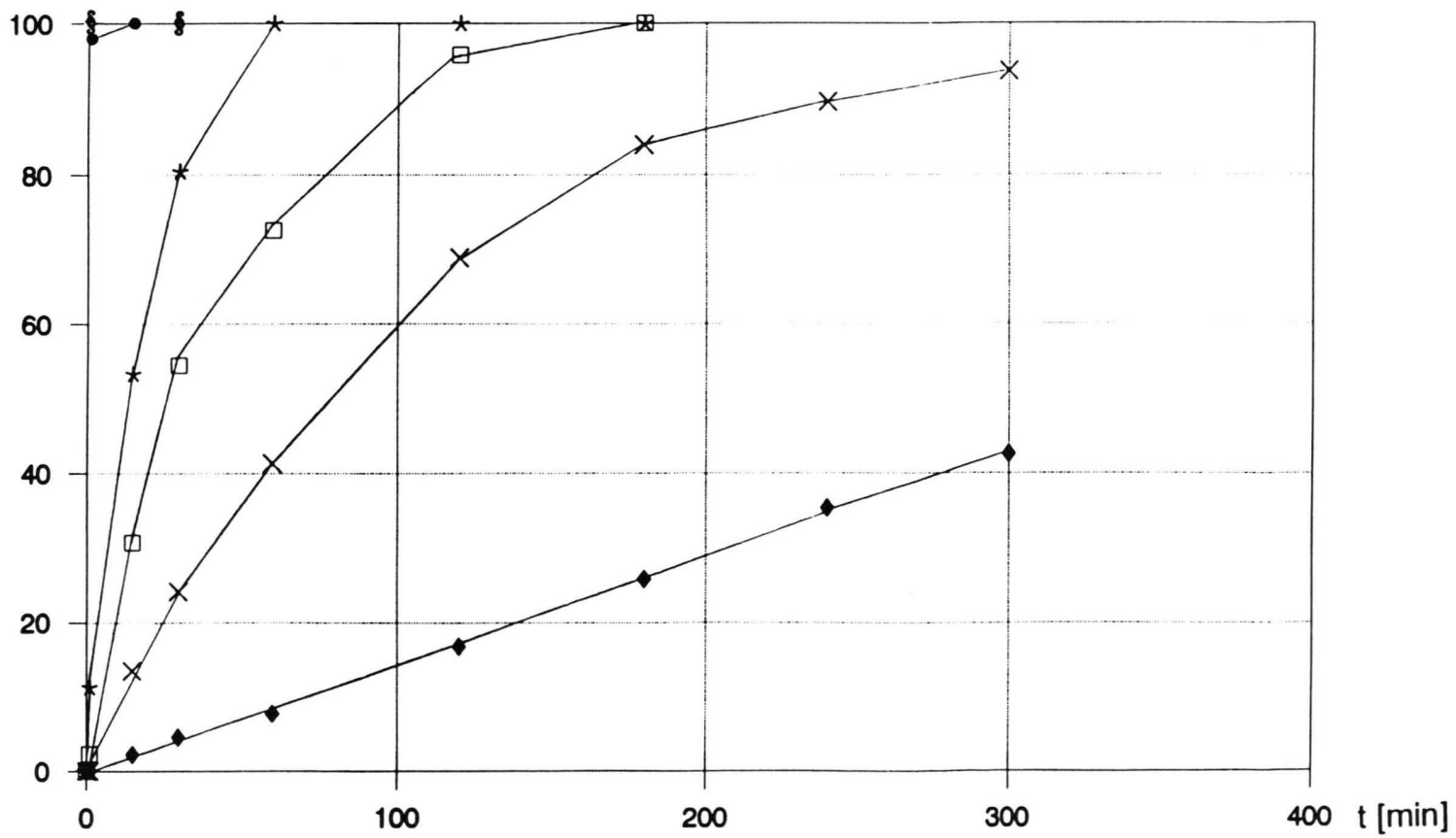

Fig. 3. Cleavage kinetics of the Mtr, Tip, Mtbs and Phen groups from Fmoc-Arg derivatives under the following acidolytic conditions: Phen - TFA/MSA (80:20); Mtbs $\times=$ TFA/MSA (80:20); Tip $\square=$ TFA/MSA (90:10); $\operatorname{Tip}^{*}=$ TFA/MSA $(80: 20)$; Mtr $=$ TFA/MSA $(90: 10)$; Mtr $\S=$ TFA/MSA $(80: 20)$. For chromatographic conditions, see legend to Fig. 1 and for kinetic investigations, see experimental. 
Table. Deprotection of $\mathrm{N}^{\mathrm{G}}$-protected Fmoc-Arg derivatives under different acidolytic conditions.

\begin{tabular}{|c|c|c|c|c|c|c|c|c|c|}
\hline \multirow{2}{*}{$\begin{array}{l}\text { Protecting } \\
\text { group }\end{array}$} & \multirow{2}{*}{$\begin{array}{l}\text { Cleavage } \\
\text { reagent }\end{array}$} & \multicolumn{8}{|c|}{ Reaction time $(\min )$ and percentage cleaved [\%] } \\
\hline & & 1 & 15 & 30 & 60 & 120 & 180 & 240 & 300 \\
\hline \multicolumn{10}{|l|}{ Mtr } \\
\hline & a & & [7.2] & [14.5] & [27.2] & [48.9] & [65.7] & [77.2] & [83.0] \\
\hline & $\mathrm{b}$ & [2.3] & [11.0] & [16.9] & [31.6] & [56.1] & [73.3] & [84.4] & [91.3] \\
\hline & c & {$[2.8]$} & [13.7] & & & & & & \\
\hline & $\mathrm{e}$ & {$[100]$} & & & & & & & \\
\hline \multicolumn{10}{|l|}{ Tip } \\
\hline & d & {$[2.3]$} & [30.8] & [54.4] & [72.6] & [95.8] & {$[100]$} & & \\
\hline & e & [11.3] & [53.2] & [80.4] & [100] & & & & \\
\hline \multicolumn{10}{|l|}{ Mtbs } \\
\hline \multirow{2}{*}{ Phen } & & & & & & & & & \\
\hline & $\mathrm{e}$ & {$[0]$} & {$[2.2]$} & {$[4.5]$} & {$[7.7]$} & {$[16.8]$} & {$[25.8]$} & [35.3] & [42.4] \\
\hline
\end{tabular}

$\mathrm{a}=$ TFA:Ani:Water $(90: 5: 5), \mathrm{b}=$ TFA: Water $(95: 5), \mathrm{c}=$ TFA:EDT: Water $(9: 5: 5), \mathrm{d}=$ TFA:MSA (90:10), $\mathrm{e}=$ TFA:MSA $(80: 20)$; TFA = Trifluoroacetic acid, Ani = Anisole, EDT = Ethanedithiol, MSA = Methanesulphonic acid.

useful than the substitution by the less bulky electron-donating methyl substituent as e.g. in Mtr. It seems that the acid lability by the substituted arylsulphonyl groups increase in the following order: tert-butyl < isopropyl < methyl, although isopropyl and tert-butyl groups are stronger electron-donating groups compared to the methyl residue. These studies also confirm the steric effects $[10,11]$, i. e. addition of a methyl group at the meta position to the sulphonyl and ortho position to the methoxy group renders the substituted sulphonyl residue less acid labile. These steric factors further explain the lethargy of $\mathbf{1 2}$ where the methoxy group is flanked by the even bulkier tert-butyl groups. Compound $\mathbf{1 7}$ is the least acid labile of the three synthesized compounds. Therefore the assumption that the possibility of extended conjugation should make the arylsulphonyl residue more acid labile can not to be confirmed by the results of our work. The result of these studies will be a fruitful help for the rational design of further substituted arylsulphonyl arginine protecting groups removable under mild conditions without causing side reactions in peptide syntheses.

\section{Experimental}

Solvents were purified and dried in the usual way; the boiling range of the petroleum ether used was $35-65^{\circ} \mathrm{C}$. N-Ethyldiisopropylamine was dried over $\mathrm{CaH}_{2}$ b. p. $126-127^{\circ} \mathrm{C}$ and stored over $\mathrm{KOH}$ pellets. - Melting points (uncorrected values): Büchi apparatus (model 510, Switzerland). - Electron impact (EI), field-desorption mass spectroscopy (FD-MS): Varian MAT 711 mass spectrometer. - TLC on silica gel $60 \mathrm{~F}_{254}$ glass plates, layer thickness $0.2 \mathrm{~mm}$ (Merck, Darmstadt). The following systems were used: A: $n$-Butanol/acetic acid/water (3:1:1); C: Petroleum ether/ $\mathrm{CH}_{2} \mathrm{Cl}_{2}$ (8:2); D: $\mathrm{CHCl}_{3} / \mathrm{CH}_{3} \mathrm{OH} / \mathrm{C}_{6} \mathrm{H}_{6} / \mathrm{H}_{2} \mathrm{O}$ (8:8:8:1), development by using first UV absorption (254), followed by ninhydrin, chlorine/o-tolidine or iodine vapours. - ${ }^{1} \mathrm{H}$ NMR and ${ }^{13} \mathrm{C}$ NMR spectra: Bruker WM 250 instrument, solvent $\mathrm{CDCl}_{3}$, DMSO- $\mathrm{d}_{6}$, internal standard tetramethylsilane (TMS). - Optical rotation: Carl-Zeiss polarimeter 370748 (Germany), 1-dm cell. - Column chromatography: silica gel $60(0.063-0.200 \mu \mathrm{m}$, Merck), aluminium oxide basic (Macherey-Nagel; Düren), silica gel for flash chromatography $(4 \mu \mathrm{m}$, J. T. Baker). - Analytical HPLC: Eppendorf-Biotronik (Maintal) apparatus consisting of HPLC pumps (model BT 8100), a Rheodyne (USA) injection system (model 7125), UV detector (BT 8200), connected with a Shimadzu (C-R6A) chromatopac printer; or analytical runs on a Nucleosil column 120-5 $\mathrm{C}_{18} \quad\left(250 / 1 / 4^{\prime \prime} / 4.6 \mu \mathrm{m}\right) \quad$ (Macherey-Nagel; Düren) with a flow rate of $1.2 \mathrm{ml} / \mathrm{min}$. The following gradient was applied: $0-100 \% \quad \mathrm{~B}$ within 11 min; A: $40 \% \mathrm{CH}_{3} \mathrm{CN}$ and $0.015 \%$ TFA in $\mathrm{H}_{2} \mathrm{O}$, B: $80 \% \mathrm{CH}_{3} \mathrm{CN}$ and $0.015 \%$ TFA in $\mathrm{H}_{2} \mathrm{O}$ (detection at $301 \mathrm{~nm})$. - pH measurements: Knick pHmeter. 


\section{$N^{\alpha}$-Benzyloxycarbonyl-L-arginine \\ $(\mathrm{Z}-\mathrm{L}-\mathrm{Arg}-\mathrm{OH}, \mathbf{3})$}

L-Arginine ( $30 \mathrm{~g}, 172 \mathrm{mmol}$ ) was suspended in $0.5 \mathrm{~N} \mathrm{NaOH}(150 \mathrm{ml})$ and the suspension was cooled to $0{ }^{\circ} \mathrm{C}$ with continuous stirring. Benzyl chloroformate $(25 \mathrm{ml}, 177.31 \mathrm{mmol})$ was carefully added to bring the $\mathrm{pH}$ between 9-10. After the addition of benzyl chloroformate was completed, the reaction mixture was stirred for further $2 \mathrm{~h}$ at $0{ }^{\circ} \mathrm{C}$ and the $\mathrm{pH}$ was allowed to decrease to $7.0-$ 7.5 and this value was maintained till the completion of the reaction. The precipitate was filtered, washed with water, recrystallized from hot water $\left(70{ }^{\circ} \mathrm{C}\right)$ and dried in high vacuum to afford $42.5 \mathrm{~g}(80 \%)$ of 3. - M.p. $=184^{\circ} \mathrm{C}($ dec. $)[\alpha]_{\mathrm{D}}=$ $-9.3(\mathrm{c}=2,1 \mathrm{~N} \mathrm{HCl})$. - TLC $\left(R_{f}=0.3\right.$ in system D). - MS (FD): $m / z(\%)=308.4\left(\mathrm{M}^{+}\right)$.

$\begin{array}{rrrr}\mathrm{C}_{14} \mathrm{H}_{20} \mathrm{~N}_{4} \mathrm{O}_{4} & (308.33) \\ \text { Calcd } & \mathrm{C} 54.53 & \text { H } 6.53 & \text { N } 18.17 \%, \\ \text { Found } & \text { C } 54.46 & \text { H } 6.76 & \text { N } 18.01 \% .\end{array}$

$N^{\alpha}$-Benzyloxycarbonyl- $N^{G}-2,4,6$-triisopropylbenzenesulphonyl-L-arginine

$(\mathrm{Z}-\mathrm{L}-\operatorname{Arg}(\mathrm{Tip})-\mathrm{OH}, \mathbf{4})$

$\mathrm{Z}-\mathrm{L}-\mathrm{Arg}-\mathrm{OH}(3.0 \mathrm{~g}, 9.72 \mathrm{mmol})$ was suspended in THF $(50 \mathrm{ml})$ and with continuous stirring $4 \mathrm{~N} \mathrm{NaOH}$ solution was added till the $\mathrm{pH}$ was $12-13$. The solution obtained was cooled to $0{ }^{\circ} \mathrm{C}$ and 2,4,6-triisopropylbenzenesulphonyl chloride (4.5 g, $14.85 \mathrm{mmol})$, dissolved in THF $(25 \mathrm{ml})$ was added dropwise in such a way that the value of $\mathrm{pH}$ remained between $12-13$ and the temperature did not rise above $5{ }^{\circ} \mathrm{C}$ during the addition. The reaction mixture was stirred for $2 \mathrm{~h}$ at $0{ }^{\circ} \mathrm{C}$ and for further $3 \mathrm{~h}$ at room temperature. After completion of the reaction, cold water $(100 \mathrm{ml})$ was added and the reaction mixture was neutralized by $3 \mathrm{~N} \mathrm{HCl}$ and concentrated on a rotary evaporator till all the THF was removed. To the aqueous solution $4 \mathrm{~N}$ citric acid solution was added till the $\mathrm{pH}$ was between 3-4. The aqueous solution was extracted two times with ethyl acetate. The organic phase was washed with water, dried over anhydrous sodium sulphate and the solvent evaporated in rotary vacuum evaporator to afford $3.45 \mathrm{~g}(61.7 \%)$ of 4. - M.p. $=148-150{ }^{\circ} \mathrm{C} \cdot[\alpha]_{\mathrm{D}}=-3.9(\mathrm{c}=2$, DMF). - TLC $\left(R_{f}=0.4\right.$ in system D/acetone, 4:6). - MS (FD): $m / z(\%)=575.2\left(\mathrm{M}^{+}+1\right)$.

$$
\begin{array}{ccccc}
\mathrm{C}_{29} \mathrm{H}_{42} \mathrm{~N}_{4} \mathrm{O}_{6} \mathrm{~S}(574.74) & & & \\
\text { Calcd } & \mathrm{C} 60.60 & \mathrm{H} 7.37 & \text { N } 9.75 & \text { S } 5.58 \%, \\
\text { Found } & \mathrm{C} 60.42 & \mathrm{H} 7.37 & \text { N } 9.49 & \text { S } 5.70 \% .
\end{array}
$$

$N^{G}$-2,4,6-Triisopropylbenzenesulphonyl-Larginine acetate $(\mathrm{H}-\mathrm{L}-\mathrm{Arg}(\mathrm{Tip})-\mathrm{OH}$. HOAc, 5)

$\mathrm{Z}-\mathrm{L}-\mathrm{Arg}$ (Tip)-OH (3.0 g, $5.21 \mathrm{mmol})$ was dissolved in glacial acetic acid $(100 \mathrm{ml})$ and was hydrogenated for $6 \mathrm{~h}$ over activated $(0.5 \mathrm{~g}) 10 \% \mathrm{Pd} /$ $\mathrm{C}$, whereby the reaction was completed. The reaction mixture was filtered over a bed of Celite. Toluene was added to the residue and evaporated in vacuo till all the acetic acid was removed. The residue was further dried in high vacuum to afford $2.26 \mathrm{~g}(86.5 \%)$ of $\mathbf{5}$. - TLC $\left(R_{f}=0.3\right.$ in system A/ethyl acetate/methanol 4:1:1). - M.p. $=148-$ $150{ }^{\circ} \mathrm{C} .[\alpha]_{\mathrm{D}}=-2.4(\mathrm{c}=1, \mathrm{DMF}) .-\mathrm{MS}(\mathrm{FD})$ : $m / z(\%)=440.1\left(\mathrm{M}^{+}-\mathrm{HOAc}\right)$.

$$
\begin{array}{ccccc}
\mathrm{C}_{23} \mathrm{H}_{46} \mathrm{~N}_{4} \mathrm{O}_{6} \mathrm{~S} & (500.66) \\
\text { Calcd } & \text { C } 55.17 & \mathrm{H} 8.05 & \text { N } 11.19 & \mathrm{~S} 6.40 \%, \\
\text { Found } & \text { C } 55.30 & \mathrm{H} 7.87 & \text { N } 10.88 & \text { S } 6.42 \% .
\end{array}
$$

$N^{\alpha}$-9-Fluorenylmethyloxycarbonyl- $N^{G}-2,4,6-$ triisopropylbenzenesulphonyl-L-arginine (Fmoc-L-Arg(Tip)-OH, 6)

$\mathrm{H}-\mathrm{L}$-Arg(Tip)-OH.HOAc (1.98 g, $3.95 \mathrm{mmol})$ was suspended in a mixture of acetonitrile/water 60:40 $(50 \mathrm{ml})$. Freshly distilled triethylamine was added to adjust the $\mathrm{pH}$ between $8-9$. The solution was cooled to $0^{\circ} \mathrm{C}$ and a solution of $\mathrm{Fmoc}-\mathrm{OSu}$ $(1.3 \mathrm{~g}, 3.85 \mathrm{mmol})$ in acetonitrile $(30 \mathrm{ml})$ was added to it in one portion. Triethylamine was added to hinder the sharp drop of $\mathrm{pH}$ due to the liberation of free $\mathrm{N}$-hydroxysuccinimide and to maintain the $\mathrm{pH}$ at 8.5 . The mixture was stirred for $15 \mathrm{~min}$ at $0{ }^{\circ} \mathrm{C}$ and then for $1 \mathrm{~h}$ at room temperature, whereby the reaction was completed. The solution was concentrated in vacuo and $3 \mathrm{~N}$ citric acid $(100 \mathrm{ml})$ was added to the residue which was previously cooled to $0^{\circ} \mathrm{C}$ and then the reaction mixture was extracted with ethyl acetate $(100 \mathrm{ml})$. The organic phase was washed with water till neutral, then it was dried over anhydrous sodium sulphate and filtered. This solution on concentration under vacuum yielded Fmoc-L-Arg(Tip) $-\mathrm{OH}$ (6) $1.8 \mathrm{~g} \quad(68.6 \%)$. M.p. $=122-124^{\circ} \mathrm{C},[\alpha]_{\mathrm{D}}=-5.3(\mathrm{c}=1, \mathrm{DMF})$. TLC $\left(R_{f}=0.5\right.$, system D/acetone, 4:6). - MS (FD): $m / z(\%)=662.7\left(\mathrm{M}^{+}+1\right)$.

$$
\begin{array}{ccccc}
\mathrm{C}_{36} \mathrm{H}_{46} \mathrm{~N}_{4} \mathrm{O}_{6} \mathrm{~S} & (662.85) \\
\text { Calcd } & \mathrm{C} 65.23 & \text { H } 6.99 & \text { N } 8.45 & \text { S } 4.84 \%, \\
\text { Found } & \text { C } 65.16 & \text { H } 7.15 & \text { N } 8.38 & \text { S } 4.92 \% .
\end{array}
$$

\section{2,6-Di-tert-butylanisole 7}

To 2,6-di-tert-butylphenol $(20 \mathrm{~g}, 0.097 \mathrm{~mol})$ in tert-butanol $(50 \mathrm{ml})$ was added $105 \mathrm{ml}(0.101 \mathrm{~mol})$ of $0.963 \mathrm{~N}$ solution of potassium-tert-butoxide in 
tert-butanol under argon at room temperature with constant stirring, a light green precipitate formed which was dissolved by the addition of tetraethylene glycol dimethyl ether $(50 \mathrm{ml})$. To the resulting green solution methyl iodide (freshly distilled) $25 \mathrm{ml}(0.398 \mathrm{~mol})$ was added. As the reaction progressed, the green color changed to yellow. The reaction was completed in $9 \mathrm{~h}$, after which the resulting product was poured into cold water and extracted with petroleum ether. The organic phase was washed with water and dried over anhydrous sodium sulphate. Removal of the solvent resulted in a yellow gummy liquid $17.4 \mathrm{~g}(81.5 \%) .3 \mathrm{~g}$ of the crude product was purified on a basic alumina column. Elution with petroleum ether/diethyl ether (9:1) afforded a light yellow liquid $2.4 \mathrm{~g}$ $(75 \%)$. - TLC $\left(R_{f}=0.45\right.$; petroleum ether $) .-{ }^{1} \mathrm{H}$ NMR $\left(\mathrm{CDCl}_{3}\right): \mathrm{d}=1.54\left[\mathrm{~s}, 18 \mathrm{H}, \mathrm{C}\left(\mathrm{CH}_{3}\right)_{3}\right], 3.78$ $\left(\mathrm{s}, 3 \mathrm{H}, \mathrm{OCH}_{3}\right)$. - MS (EI): $m / z(\%)=220.1(27)$ $\left[\mathrm{M}^{+}\right]$.

$$
\begin{array}{ccc}
\mathrm{C}_{15} \mathrm{H}_{24} \mathrm{O}(220.35) & \\
\text { Calcd } & \mathrm{C} 81.76 & \mathrm{H} 10.98 \%, \\
\text { Found } & \text { C } 81.25 & \text { H } 10.88 \% .
\end{array}
$$

\section{4-Methoxy-3,5-di-tert-butylbenzenesulphonic acid potassium salt $\mathbf{8}$}

2,6-Di-tert-butylanisole ( $12.0 \mathrm{~g}, 54.45 \mathrm{mmol})$ was dissolved in dichlormethane $(50 \mathrm{ml})$ and the solution was cooled to $0^{\circ} \mathrm{C}$ and chlorosulphonic acid $(4.2 \mathrm{ml}, 63.07 \mathrm{mmol})$ was added dropwise. The reaction mixture was stirred for $1 \mathrm{~h}$ at $0{ }^{\circ} \mathrm{C}$ and then for further $30 \mathrm{~min}$ at room temperature. After this period, water $(100 \mathrm{ml})$ was added, dichloromethane was removed under reduced pressure. A saturated $\mathrm{KCl}$ solution $(25 \mathrm{ml})$ was added to obtain the title compound $10.5 \mathrm{~g}(57 \%)$.

\section{4-Methoxy-3,5-di-tert-butylbenzenesulphonyl chloride 9}

To 4-methoxy-3,5-di-tert-butylbenzenesulphonic acid potassium salt $(10 \mathrm{~g}, 29.58 \mathrm{mmol}) \mathrm{PCl}_{5}(10 \mathrm{~g}$, $47.99 \mathrm{mmol})$ and $\mathrm{POCl}_{3}(5 \mathrm{ml})$ was added. The reaction was subjected to usual work up used for obtaining sulphonyl chlorides. It resulted in the desired sulphonyl chloride $7.8 \mathrm{~g}(82.8 \%)$. - M. p. = $86-87^{\circ} \mathrm{C}$. - TLC $\left(R_{f}=0.5\right.$; petroleum ether $/$ dichloromethane, 8:2): - MS (EI): $m / z(\%)=$ $318.1(24)\left[\mathrm{M}^{+}\right] .-{ }^{1} \mathrm{H}$ NMR $\left(\mathrm{CDCl}_{3}\right): \mathrm{d}=1.47[\mathrm{~s}$, $\left.18 \mathrm{H}, \mathrm{C}\left(\mathrm{CH}_{3}\right)_{3}\right], 3.76\left(\mathrm{~s}, 3 \mathrm{H}, \mathrm{OCH}_{3}\right), 7.28(\mathrm{~s}, 2 \mathrm{H}$, aromatic $\mathrm{H}$ ).

$$
\begin{array}{cccccc}
\mathrm{C}_{15} \mathrm{H}_{23} \mathrm{O}_{3} \mathrm{SCl}(318.86) & & & \\
\text { Calcd } & \mathrm{C} 56.50 & \mathrm{H} 7.27 & \mathrm{~S} 10.05 & \mathrm{Cl} 11.11 \%, \\
\text { Found } & \mathrm{C} 56.58 & \mathrm{H} 7.63 & \mathrm{~S} 10.10 & \mathrm{Cl} 11.19 \% .
\end{array}
$$

$N^{\alpha}$-Benzyloxycarbonyl-NG-4-methoxy-3,5-di-tert-

butylbenzenesulphonyl-L-arginine

$(Z-L-\operatorname{Arg}(M t b s)-O H, 10)$

Compound $\mathbf{3}$ ( $3.5 \mathrm{~g}, 11.35 \mathrm{mmol}$ ) was suspended in THF $(50 \mathrm{ml})$ and then $4 \mathrm{~N} \mathrm{NaOH}$ solution was added till the $\mathrm{pH}$ raised to the value of 13 . The reaction mixture was cooled to $0{ }^{\circ} \mathrm{C}$ and then 4-methoxy-3,5-di-tert-butyl-benzenesulphonyl chloride $(7.2 \mathrm{~g}, 22.6 \mathrm{mmol})$ dissolved in THF $(50 \mathrm{ml})$ was added dropwise to this mixture. The reaction mixture was worked up as usual to afford $4.11 \mathrm{~g}(61.3 \%)$ of $\mathbf{1 0} .-$ M.p. $=138-140{ }^{\circ} \mathrm{C}$. - TLC $\left(R_{f}=0.35 ;\right.$ system D/acetone, $\left.4: 6\right) .-[\alpha]_{\mathrm{D}}=-1.70$ $(\mathrm{c}=1, \mathrm{DMF}) .-\mathrm{MS}(\mathrm{FD}): m / z(\%)=590.7\left(\mathrm{M}^{+}\right)$.

\section{$\mathrm{C}_{29} \mathrm{H}_{42} \mathrm{~N}_{4} \mathrm{O}_{7} \mathrm{~S}(590.74)$ Calcd C 58.96 H 7.16 N 9.48 S 5.42\%, Found C 58.69 H 6.82 N 8.78 S 5.38\%.}

\section{$N^{G}$-4-Methoxy-3,5-di-tert-butylbenzenesulphonyl- $L$-arginine hydrobromide $(\mathrm{H}-\mathrm{L}-\mathrm{Arg}(\mathrm{Mtbs})-\mathrm{OH}$. $\mathrm{HBr}, \mathbf{1 1})$}

$\mathrm{Z}-\mathrm{L}-\mathrm{Arg}(\mathrm{Mtbs})-\mathrm{OH} \mathbf{1 0}(4 \mathrm{~g}, 6.77 \mathrm{mmol})$ was dissolved in a solution of $15 \% \mathrm{HBr}$ /acetic acid $(15 \mathrm{ml})$. After $30 \mathrm{~min}$ the reaction mixture was worked up as usual resulting in compound $\mathbf{1 1}$ $3.20 \mathrm{~g}(88.1 \%)$. M.p. $=164^{\circ} \mathrm{C}$. $-\mathrm{TLC}\left(R_{f}=0.45\right.$; systems A/ethyl acetate/methanol, 4:1:1). $[\alpha]_{\mathrm{D}}=-4.8(\mathrm{c}=1, \mathrm{DMF})$. $-\mathrm{MS}(\mathrm{FD}): m / z(\%)=$ $538\left(\mathrm{M}^{+}+1\right)$.

$\mathrm{C}_{21} \mathrm{H}_{37} \mathrm{~N}_{4} \mathrm{O}_{5} \mathrm{SBr}$ (537.52)

Calcd C46.92 H6.93 N10.42 S5.96 Br14.86\%, Found C46.78 H6.73 N10.22 S5.81 Br14.71\%.

$N^{\alpha}$-9-Fluorenylmethyloxycarbonyl- $N^{G}-4$-methoxy3,5-di-tert-butylbenzenesulphonyl-L-arginine (Fmoc-L-Arg (Mtbs) $-\mathrm{OH}, \mathbf{1 2})$

Compound 11 ( $3.0 \mathrm{~g}, 5.58 \mathrm{mmol})$ was dissolved in acetonitrile/water 1:1 $(25 \mathrm{ml})$ and the solution was basified with triethylamine up to $\mathrm{pH} 8.5$. Fmoc-OSu (2.1 g, $6.23 \mathrm{mmol})$, dissolved in acetonitrile $(10 \mathrm{ml})$, was added in one portion and the reaction was worked up as usual to afford the required compound 12 yield $2.14 \mathrm{~g}$ (56.5\%). M.p. $=150-152^{\circ} \mathrm{C}$. - TLC $\left(R_{f}=0.28\right.$; system D/ acetone, $4: 6) .-[\alpha]_{\mathrm{D}}=-5.10(\mathrm{c}=1 ; \mathrm{DMF}) .-\mathrm{MS}$ (FD): $m / z(\%)=678.4\left(\mathrm{M}^{+}\right)$.

$$
\begin{array}{ccccc}
\mathrm{C}_{36} \mathrm{H}_{46} \mathrm{~N}_{4} \mathrm{O}_{7} \mathrm{~S}(678.85) & & & \\
\text { Calcd } & \mathrm{C} 63.69 & \mathrm{H} 6.83 & \text { N } 8.25 & \mathrm{~S} 4.72 \%, \\
\text { Found } & \mathrm{C} 63.55 & \mathrm{H} 6.48 & \text { N } 8.01 & \mathrm{~S} 4.60 \% .
\end{array}
$$




\section{Phenanthrene-3-sulphonic acid potassium salt $\mathbf{1 3}$}

Phenanthrene (50 g, $0.28 \mathrm{~mol}$ ) was sulphonated with concentrated sulphuric acid $(327 \mathrm{ml}, 5.8 \mathrm{~mol})$ at $120^{\circ} \mathrm{C}$, whereby a mixture of 2 - and 3 -phenanthrenesulphonic acids together with some disulphonated product were obtained. The reaction mixture was worked up according to the procedure described in [19], phenanthrene-3-sulphonic acid was obtained in the form of its potassium salt $5.2 \mathrm{~g}(6.2 \%)$.

\section{Phenanthrene-3-sulphonyl chloride $\mathbf{1 4}$}

Phenanthrene-3-sulphonic acid potassium salt $(5 \mathrm{~g}, 16.89 \mathrm{mmol})$ was moistened with $\mathrm{POCl}_{3}$ $(3 \mathrm{ml})$ and $\mathrm{PCl}_{5}(5 \mathrm{~g}, 24.01 \mathrm{mmol})$ and mixed with a pestle and mortar. The reaction mixture was then subjected to usual work up adopted from other sulphonyl chlorides. Recrystallization was affected with benzene/petroleum ether $(1: 1)$ to afford $3.90 \mathrm{~g}(83.5 \%)$. - M.p. $=108^{\circ} \mathrm{C}$. - TLC $\left(R_{f}=0.24 ;\right.$ petroleum ether/dichloromethane, $8: 2) .-(\mathrm{EI}): m / z(\%)=276.1(26)\left[\mathrm{M}^{+}\right]$.

$$
\begin{aligned}
& \mathrm{C}_{14} \mathrm{H}_{9} \mathrm{O}_{2} \mathrm{SCl} \text { (276.74) } \\
& \text { Calcd C } 60.76 \text { H3.27 S } 11.58 \text { Cl 12.81\%, } \\
& \text { Found C } 60.56 \text { H3.25 S } 11.58 \mathrm{Cl} 13.01 \% \text {. }
\end{aligned}
$$

$N^{\alpha}$-Benzyloxycarbonyl- $N^{G}$-phenanthrene-

3-sulphonyl-L-arginine $(Z-L-A r g(P h e n) O H, 15)$

This compound was prepared from phenanthrene-3-sulphonyl chloride $(3.5 \mathrm{~g}, 12.64 \mathrm{mmol})$ and $\mathrm{Z}-\mathrm{L}-\mathrm{Arg}-\mathrm{OH}(2.5 \mathrm{~g}, 8.10 \mathrm{mmol})$ using the procedure described for the preparation of $\mathbf{4}$ to afford $2.80 \mathrm{~g}(62.9 \%)$ of $\mathbf{1 5}$. - M.p. $=186-$ $188^{\circ} \mathrm{C}$. - TLC $\left(R_{f}=0.22\right.$; system D/acetone $4: 6) .-[\alpha]_{\mathrm{D}}=-5.67(\mathrm{c}=0.6, \mathrm{DMF}) .-\mathrm{MS}(\mathrm{FD})$ : $m / z(\%)=549\left(\mathrm{M}^{+}\right)$.

$$
\begin{array}{ccccc}
\mathrm{C}_{28} \mathrm{H}_{28} \mathrm{~N}_{4} \mathrm{O}_{6} \mathrm{~S} & (548.62) \\
\text { Calcd } & \mathrm{C} 61.31 & \mathrm{H} 5.15 & \mathrm{~N} 10.22 & \text { S } 5.85 \%, \\
\text { Found } & \mathrm{C} 61.21 & \mathrm{H} 4.98 & \mathrm{~N} 10.01 & \text { S } 5.65 \% .
\end{array}
$$

\section{$N^{G}$-Phenanthrene-3-sulphonyl-L-arginine hydrobromide (H-L-Arg(Phen)-OH. $\mathrm{HBr}, \mathbf{1 6})$}

Compound 15 (2.5 g, $4.55 \mathrm{mmol})$ was dissolved in a solution of $15 \% \mathrm{HBr} /$ acetic acid $(15 \mathrm{ml})$. The reaction mixture was stirred at room temperature for $30 \mathrm{~min}$ and then the excess of $\mathrm{HBr} /$ acetic acid was removed in vacuum and the residue was evaporated several times with toluene for azotropic removal of the acetic acid to afford $1,8 \mathrm{~g}$ of an amorphous solid (80\%). - TLC $\left(R_{f}=0.2\right.$; system A/ethyl acetate/methanol, 4:1:1). - M.p. = $174-176{ }^{\circ} \mathrm{C} .-[\alpha]_{\mathrm{D}}=-1.5(\mathrm{c}=1) .-\mathrm{MS}(\mathrm{FD})$ : $m / z(\%)=496\left(\mathrm{M}^{+}+1\right)$.

$\mathrm{C}_{20} \mathrm{H}_{23} \mathrm{~N}_{4} \mathrm{O}_{4} \mathrm{SBr}(495.40)$

Calcd C48.50 H4.68 N11.30 S6.47 Br16.13\%, Found C48.60 H4.43 N11.02 S6.11 Br15.87\%.

$N^{\alpha}$-9-Fluorenylmethyloxycarbonyl-

$N^{G}$-phenanthrene-3-sulphonyl-L-arginine

(Fmoc-L-Arg(Phen)-OH, 17)

The title compound was prepared using compound 16 (1.80 g, $3.63 \mathrm{mmol})$ and Fmoc-OSu $(1.4 \mathrm{~g}, 4.15 \mathrm{mmol})$ following the procedure used for the preparation of compound $\mathbf{6} ; 1.33 \mathrm{~g}$ $(57.57 \%) .-$ M.p. $=146-147^{\circ} \mathrm{C} .-\operatorname{TLC}\left(R_{f}=\right.$ 0.25 ; system D/acetone, $4: 6) .-[\alpha]_{\mathrm{D}}=-5.10(\mathrm{c}=$ 1, DMF). - MS (FD): $m / z(\%)=637\left(\mathrm{M}^{+}\right)$.

$$
\begin{array}{ccccc}
\mathrm{C}_{35} \mathrm{H}_{32} \mathrm{~N}_{4} \mathrm{O}_{6} \mathrm{~S}(636.73) & & & \\
\text { Calcd } & \mathrm{C} 66.02 & \mathrm{H} 5.66 & \text { N } 8.79 & \text { S } 5.03 \%, \\
\text { Found } & \mathrm{C} 66.20 & \mathrm{H} 5.49 & \text { N } 8.29 & \text { S } 4.92 \% .
\end{array}
$$

\section{Kinetic investigations}

$5 \mathrm{mg}$ Fmoc-Arg(Mtr)-OH (2) and the corresponding Tip (6), Mtbs (12) and Phen (17) derivatives were dissolved in the systems a-e each (see Table). $50 \mathrm{ml}$ aliquots were drawn after 1, 15, 30, $60,120,180,240$ and $300 \mathrm{~min}$ intervals and then $1000 \mu \mathrm{l}$ buffer $\mathrm{A}\left(40 \% \mathrm{CH}_{3} \mathrm{CN}\right.$ and $0.015 \%$ TFA in water) were added. In case of system $d$ and $e$ the $\mathrm{pH}$ was maintained at 3-4 by the addition of $\mathrm{N}$-ethyldiisopropyl amine $(\mathrm{ca} .101-102 \mu \mathrm{l})$. Finally $300 \mu \mathrm{l}$ were injected into the HPLC system. For chromatographic conditions see legends to the Figures 2 and 3.

\section{Acknowledgement}

Syed Safdar Ali and Mashooda Hasan wish to thank DAAD and Khalid Mohammed Khan Ministry for Science and Baden-Württemberg for financial support. The support of these studies by the Fonds der Chemischen Industrie is greatly acknowledged. 
[1] "E. Wünsch", Methoden Org. Chem. (HoubenWeyl) 4 th ed. vol. "15", part 1 and 2, Thieme Verlag, Stuttgart (1974).

[2] M. Bergmann, L. Zervas, H. Rinke, Hoppe-Seyler's Z. Physiol. Chem., 224, 40 (1934).

[3] R. Schwyzer, C. H. Li, Nature 182, 1669 (1958).

[4] E. Schnabel, Justus Liebigs Ann. Chem. 702, 188 (1967).

[5] R. Colombo, Experientia 37, 798 (1981).

[6] R. Presentini, G. Antoni, Int. J. Peptide Protein Res. 27, 123 (1986).

[7] P. Neri, G. Antoni, G. Barbarulli, C. Casagli, M. Mariani, L. Nencioni, R. Presentini, A. Tagliabue, Mol. Immunol. 21, 151 (1984).

[8] E. Atherton, R. C. Sheppard, in S. Udenfriend, J. Meienhofer (eds): The Peptides, vol. 9, p. 1, Academic Press, New York (1987).

[9] H. Rink, P. Sieber, F. Raschdorf, Tetrahedron Lett. 25, 621 (1984).

[10] M. Fujino, M. Wakimasu, C. Kitada, Chem. Pharm. Bull. 29, 2825 (1981).
[11] R. Ramage, J. Green, Tetrahedron Lett. 28, 2287 (1987).

[12] E. Atherton, R. C. Sheppard, J. D. Wade, J. Chem. Soc. Chem. Commun. 1060 (1983).

[13] J. Green, O. M. Ogunjobi, R. Ramage, A. S. J. Stewart, S. McCurdy, R. Noble, Tetrahedron Lett. 29, 4341 (1988).

[14] A. G. Beck-Sickinger, G. Schnorrenberg, J. Metzger, G. Jung, Int. J. Pept. Protein Res. 38, 25 (1991).

[15] P. M. Fischer, K. V. Retson, M. I. Tyler, M. E. H. Howden, Int. J. Pept. Protein Res. 40, 19 (1992).

[16] P. Sieber, Tetrahedron Lett. 28, 1637 (1987).

[17] H. Echner, W. Voelter, Z. Naturforsch. 42b, 1591 (1987).

[18] M. Bergmann, L. Zervas, Chem. Ber. 65, 1192 (1932).

[19] P. B. W. Ten Kortenaar, B. G. Van Dijk, J. Marjolijn Peeters, B. J. Raaben, P. J. H. M. Adams, G. I. Tesser, Int. J. Pept. Protein Res. 27, 398 (1986).

[20] L. F. Fieser, Org. Synth. Coll. Vol. II, 482 (1943). 